\title{
Effect of Vitamin E on Arginase Activity in the Liver and Kidneys of Testosterone-Treated and Castrated Rabbits
}

\author{
M. ERISIR ${ }^{1 *}$, N. AYDILEK ${ }^{2}$, M. AKSAKAL ${ }^{3}$ \\ ${ }^{1}$ Department of Biochemistry, Veterinary Faculty of Firat University, Elazig, Turkey \\ ${ }^{2}$ Department of Physiology, Veterinary Faculty of Harran University, Urfa, Turkey \\ ${ }^{3}$ Department of Physiology, Veterinary Faculty of Firat University, Elazig, Turkey
}

Received October 25, 2004

Accepted June 3, 2005

\begin{abstract}
Erisir M., N. Aydilek, M. Aksakal: Effect of Vitamin E on Arginase Activity in the Liver and Kidneys of Testosterone-Treated and Castrated Rabbits. Acta Vet. Brno 2005, 74:527-531.

In the present study we examined the effect of vitamin $\mathrm{E}$ administration on arginase activity in the liver and kidneys of testosterone-treated and castrated rabbits. Forty-six 3-month-old male rabbits were divided into six groups: 1) control rabbits, $0.5 \mathrm{ml}$ olive oil; 2) testosterone-treated rabbits, $10 \mathrm{mg}$ of testosterone propionate dissolved in $0.5 \mathrm{ml}$ olive oil; 3) bilaterally castrated rabbits, $0.5 \mathrm{ml}$ olive oil; 4) vitamin E-treated rabbits, $100 \mathrm{mg} / \mathrm{kg}$ dl- $\alpha$-tocopheryl acetate dissolved in $0.5 \mathrm{ml}$ olive oil; 5) vitamin E- and testosterone-treated rabbits, $100 \mathrm{mg} / \mathrm{kg}$ dl- $\alpha$-tocopheryl acetate and $10 \mathrm{mg}$ testosterone propionate dissolved in $0.5 \mathrm{ml}$ olive oil; 6) bilaterally castrated and vitamin E-treated rabbits, $100 \mathrm{mg} / \mathrm{kg}$ dl- $\alpha$-tocopheryl acetate dissolved in $0.5 \mathrm{ml}$ olive oil. The administration was done subcutaneously over $24 \mathrm{~h}$ for 40 days; then the arginase activities in the liver and kidneys were determined.

Liver arginase activities in all the groups did not change significantly $(p>0.05)$. Kidney arginase activities were not affected by castration and vitamin E. Kidney arginase activity was found to have increased two-fold by testosterone treatment. Testosterone-induced arginase activity in the kidneys returned to normal level with a significant lowering effect of the combination of vitamin $\mathrm{E}$ and testosterone.

These results indicate that vitamin E supplementation has a significant reducing effect on the testosterone-induced arginase activity in the kidneys. Vitamin E ameliorates the testosteroneinduced arginase activity in the kidneys.
\end{abstract}

Arginase, testosterone, castration, vitamin E

Arginase catalyzes the hydrolysis of L-arginine to form L-ornithine and urea (L-arginine amidinohydrolase, EC 3.5.3.1). This reaction comprises the final cytosolic step of the urea cycle, which provides the principal route for the disposal of nitrogenous waste from protein catabolism. Although arginase activity is most abundant in the mammalian liver where the urea cycle is most active, it is also found in non-hepatic tissues such as the kidney (Herzfeld and Raper 1976). The kidney does not contain an active urea cycle (Ratner and Petrack 1953), and kidney arginase is probably involved in the catabolism of arginine for use as a source of proline or glutamate, and polyamines (Kaysen and Strecker 1973; Manteuffel-Cymborows ka et al. 1993; 1995). Since the liver and kidney arginase types differ in their regulation by certain steroid hormones (Kumar and Kalyankar 1984), by pattern of expression in patients with hyperargininemia (Spector et al. 1983), by electrophoretic mobility and by immunologic relatedness (Skryzpek-Osiecka and Porembska 1983; Porembska and Zamecka 1984; Porembska et al. 1993), they appear to be distinct polypeptides encoded by two different genes (Haggerty et al. 1983).

Vitamin E maintains homeostasis in living cells (Gallo-Torres 1980). Park and Tappel (1991) reported a relationship between vitamin $\mathrm{E}$ and arginase: rats fed a vitamin 
E supplemented diet had a lower liver arginase activity than those fed a vitamin E deficient diet. Arginase is known to be inducible by hormones (Mimic-Oka et al. 1971; Y a manaka et al. 1971; Kumar and Kalyankar 1984; Patnaik and Patnaik 1989). This effect can be prevented by vitamin E. Therefore, we examined the effects of vitamin E supplementation on arginase activity in the liver and kidneys of testosterone-treated and castrated rabbits.

\section{Materials and Methods}

Animals and Treatments

The experiment was conducted on forty-six 3-month-old clinically healthy adult male New Zealand White rabbits weighing $2600 \pm 300 \mathrm{~g}$, which were housed one per cage at room temperature of $20{ }^{\circ} \mathrm{C}$. During a 10 -day adaptation period, the animals were given a basic diet and tap water ad libitum. At the end of this period, the rabbits were divided into six groups: 1) control rabbits, $0.5 \mathrm{ml}$ olive oil; 2) testosterone-treated rabbits, $10 \mathrm{mg}$ of testosterone propionate dissolved in $0.5 \mathrm{ml}$ olive oil; 3) bilaterally castrated rabbits, $0.5 \mathrm{ml}$ olive oil; 4) vitamin Etreated rabbits, $100 \mathrm{mg} / \mathrm{kg}$ dl- $\alpha$-tocopheryl acetate dissolved in $0.5 \mathrm{ml}$ olive oil; 5) vitamin E- and testosteronetreated rabbits, $100 \mathrm{mg} / \mathrm{kg}$ dl- $\alpha$-tocopheryl acetate and $10 \mathrm{mg}$ testosterone propionate dissolved in $0.5 \mathrm{ml}$ olive oil; 6) bilaterally castrated and vitamin E-treated rabbits, $100 \mathrm{mg} / \mathrm{kg}$ d- $\alpha$-tocopheryl acetate dissolved in $0.5 \mathrm{ml}$ olive oil. This administration was done subcutaneously over $24 \mathrm{~h}$ for 40 days.

At the end of the experiment, the rabbits were anesthetized and the liver and kidneys were excised and rinsed in cold saline $(0.9 \% \mathrm{NaCl})$. One gram of liver and kidney tissues was weighed and homogenized with 10 volumes of $10 \mathrm{mM}$ Tris-HCl buffer $\mathrm{pH}$ (7.4) in a glass Potter Elvehjem homogenizer in an ice bath. The homogenates were centrifuged at $20000 \mathrm{~g}$ for $10 \mathrm{~min}$ at $4{ }^{\circ} \mathrm{C}$. The supernatants were used for the arginase assay.

\section{Arginase assay}

Arginase activity was measured by determining the increase in the amount of the reaction product, urea (Gey er and Dabich 1971). One unit (U) of enzyme activity was defined as $\mu$ mole of the product formed per hour at $37^{\circ} \mathrm{C}$. The results are given as units/ $\mathrm{mg}$ of protein.

Protein determination

The protein content of tissue samples was assayed according to the method of Lowry et al. (1951). The bovine serum albumin was used as the standard.

Statistical Analysis

Results were expressed as mean \pm SEM. Analysis of variance (ANOVA) followed by the Duncan test were used to determine significant differences among the groups. A 5\% level of significance was used to establish differences.

\section{Results}

Liver arginase activities in all the groups did not change significantly $(p>0.05)$. Kidney arginase activities were not affected by castration and vitamin E. No significant differences were found in kidney arginase activity in the combination group compared to the controls $(p>0.05)$. Kidney arginase activity increased two-fold by testosterone treatment. The increase in kidney arginase activity induced by testosterone was reduced by vitamin E supplementation (Table 1).

Table 1. Effect of vitamin E administration on arginase activity (units / mg protein) in the liver and kidneys of testosterone-treated and castrated rabbits

\begin{tabular}{|c|c|c|c|c|c|c|c|}
\hline & $\begin{array}{l}\text { Control } \\
\bar{x} \pm \mathrm{S}_{\mathrm{X}}^{-}\end{array}$ & $\begin{array}{c}\text { Testosterone } \\
\overline{\mathrm{X}}^{-} \pm \mathrm{S}_{\mathrm{X}}^{-}\end{array}$ & $\begin{array}{l}\text { Castration } \\
-\overline{\mathrm{X}} \pm \mathrm{S}_{\mathrm{X}}^{-}\end{array}$ & $\begin{array}{l}\text { Vitamin } \mathrm{E} \\
\overline{\mathrm{X}} \pm \mathrm{S}_{\mathrm{x}}^{-}\end{array}$ & $\begin{array}{c}\text { Testosterone }+ \\
\text { Vitamin E } \\
\bar{X} \pm S_{x}^{-}\end{array}$ & $\begin{array}{c}\text { Castration }+ \\
\text { Vitamin } \mathrm{E} \\
\overline{\mathrm{X}} \pm \mathrm{S}_{\mathrm{x}}^{-}\end{array}$ & $P$ \\
\hline Liver & $\begin{array}{c}299.34 \pm 31.23 \\
n=7\end{array}$ & $\begin{array}{c}273.49 \pm 13.36 \\
n=7\end{array}$ & $\begin{array}{c}244.72 \pm 3.70 \\
n=6\end{array}$ & $\begin{array}{c}267.83 \pm 31.82 \\
n=8\end{array}$ & $\begin{array}{c}223.51 \pm 10.45 \\
n=8\end{array}$ & $\begin{array}{c}257.52 \pm 34.65 \\
n=6\end{array}$ & $\mathrm{NS}$ \\
\hline Kidney & $\begin{array}{c}4.33 \pm 0.79^{\mathrm{a}} \\
\mathrm{n}=8\end{array}$ & $\begin{array}{c}8.72 \pm 1.29^{b} \\
n=9\end{array}$ & $\begin{array}{c}5.22 \pm 0.90^{\mathrm{a}} \\
\mathrm{n}=6\end{array}$ & $\begin{array}{c}4.47 \pm 0.70^{\mathrm{a}} \\
\mathrm{n}=8\end{array}$ & $\begin{array}{c}5.81 \pm 0.94^{\mathrm{a}} \\
\mathrm{n}=8\end{array}$ & $\begin{array}{c}5.01 \pm 0.82^{\mathrm{a}} \\
\mathrm{n}=7\end{array}$ & $*$ \\
\hline
\end{tabular}

NS: Not significant

$* p<0.05$

The differences between the means, marked with different letters (i.e. a, b) within the same line, were statistically significant $(p<0.05)$. 


\section{Discussion}

Liver and kidney arginases differ in their response to different steroid hormones (MimicOka et al. 1971; Kumar and Kalyankar 1984). It has been established that glucocorticoids increase the activity of liver arginase (Mimic-Oka et al. 1971; Kumar and Kalyankar 1984; Patnaik and Patnaik 1989; Grofte et al. 1998). Different glucocorticoids have different effects on arginase in the kidney. Bilateral adrenalectomy decreased significantly the activity of the kidney cortex arginase in rats, whereas hydrocortisone administered to adrenalectomized rats increased it (Patnaik and Patnaik 1989). Furthermore, renal arginase was much more sensitive than liver arginase to exogenous hydrocortisone; its activity increased by $100 \%$ after the injection of small doses of hydrocortisone (Mimic-Oka et al. 1971). On the contrary, Kumar and Kalyankar (1984) did not observe any change in the specific activity of kidney arginase in rats treated with corticosterone.

Kumar and Kalyankar (1984) observed a two-fold increase in the specific activity of kidney arginase in male rats aged $6,12,24$ and 72 weeks treated with testosterone. Testosterone stimulated kidney arginase, but had no effect on hepatic arginase (K u mar and Kalyankar 1984). Several studies have indicated that administration of testosterone increases kidney arginase activity in rats and mice (Yamanaka et al. 1971; Swank et al. 1977; Kumar and Kalyankar 1984; Manteuffel-Cymborowska et al. 1995); which is due to increased synthesis of the enzyme protein (Frieden and Fishel 1968). We also determined that testosterone treatment induced kidney arginase activity without any effect on the liver enzyme in the male rabbit. It has been found that castration caused no significant changes in arginase activity in the kidneys of rats, and testosterone treatment of castrated rats induced an increase in the enzyme activity (Yamanaka et al. 1971). Furthermore, Swank et al. (1977) found that hypophysectomy in female mice decreased the level of kidney arginase and that this level could be restored in hypophysectomized animals by a treatment with androgens. All these data show that the enzyme is under a regulatory control of androgens.

Park and Tappel (1991) reported that rats fed a vitamin E-supplemented diet for 40 days had a lower liver arginase activity than those fed a vitamin E-deficient diet. In the present study, we observed that vitamin E supplementation significantly reduced the increase in kidney arginase activity caused by testosterone, whereas vitamin $\mathrm{E}$ alone had no effect on liver or kidney arginase. We found that a dietary administration of vitamin $\mathrm{E}$ also had a significant reducing effect on arginase activity in the liver of rats treated with high doses of prednisolone (Erisir et al. 2003).

In contrast to liver, the kidney ornithine, formed by the action of arginase, is not further metabolized in the urea cycle because of absence of two enzymes of this cycle. Instead, it plays an important role both as a precursor of polyamines, and in the glutamate/proline pathway (Kaysen and Strecker 1973; Manteuffel-Cymborowska et al. 1993; 1995). Administration of testosterone to female mice causes hypertrophy of the kidneys paralleled by a pronounced induction of ornithine decarboxylase which generates putrescine, a substrate for the synthesis of higher polyamines (Manteuffel-Cymborowska 1993; Manteuffel-Cymborowska et al. 1993; 1997). Recent evidence shows that testosterone induces differential changes in the activity of two enzymes involved in ornithine biosynthesis (arginase) and catabolism (ornithine aminotransferase). This is evidenced by sensitive biochemical markers of renal hypertrophy, namely arginase and ornithine aminotransferase, that responded to testosterone treatment with the increase and decrease of activities, respectively (Manteuffel-Cymborowska et al. 1995). It is interesting that renal hypertrophy induced by testosterone was accompanied with an increase of arginase activity. An interesting observation in the present study was that the testosterone-induced 
kidney arginase activity was restored to normal level by vitamin E supplementation. We suggest that vitamin E may prevent kidney hypertrophy caused by testosterone, by preventing the increase in arginase activity.

More information is needed, especially corcerning the exact nature of the effect of vitamin $\mathrm{E}$ on the testosterone-induced kidney arginase activity.

\section{Vliv vitamínu $\mathbf{E}$ na aktivitu arginázy v játrech a ledvinách testosteronem ošetřených a kastrovaných králíků}

Aplikace vitamínu E výrazně snižuje aktivitu arginázy v játrech. Argináza je indukována hormony. Tomuto účinku lze předcházet vitamínem E. Proto jsme zkoumali vliv aplikace tohoto vitamínu na aktivitu arginázy v játrech a ledvinách testosteronem ošetřených a kastrovaných králíků.

Pokus byl proveden na 46 dospělých, 3 měsíce starých samcích plemene Novozélanského bílého králíka, vážících $2600 \pm 300$ g. Králíci byly rozděleni do 6ti skupin; 1 . kontrolní králíci, $0,5 \mathrm{ml}$ olivového oleje; 2 . testosteronem ošetření králíci, $10 \mathrm{mg}$ testosteronpropionátu (rozpuštěn v $0,5 \mathrm{ml}$ olivového oleje); 3 . oboustranně kastrovaní králíci a $0,5 \mathrm{ml}$ olivového oleje; 4. vitamínem E ošetření králíci $100 \mathrm{mg} / \mathrm{kg}$ dl- $\alpha$-tokopheryl acetátu (rozpuštěného v $0.5 \mathrm{ml}$ olivového oleje); 5. vitamínem E a testosteronem ošetření králíci, králíci 100 $\mathrm{mg} / \mathrm{kg}$ dl- $\alpha$-tokopheryl acetátu a $10 \mathrm{mg}$ testosteronpropionátu (rozpuštěných v $0.5 \mathrm{ml}$ olivového oleje); 6. oboustranně kastrovaní, vitamínem E a testosteronem ošetření králíci, 100 $\mathrm{mg} / \mathrm{kg}$ dl- $\alpha$-tokopheryl acetátu a $10 \mathrm{mg}$ testosteronpropionátu (rozpuštěných v $0.5 \mathrm{ml}$ olivového oleje). Tato aplikace byla provedena subkutánně po 24 hodinách po 40 dní. Na konci pokusu byla zjištěna aktivita arginázy v játrech a ledvinách.

Aktivita arginázy v játrech se v žádné ze skupin významně nezměnila $(P>0,05)$. Aktivita arginázy v ledvinách se nezměnila u kastrovaných a vitamínem E ošetřených králíků. Dvojnásobně zvýšená aktivita arginázy byla zaznamenána u králíků ošetřených testosteronem. U testosteronem vyvolané aktivity arginázy došlo k návratu na normální úroveň za významného redukujícího účinku kombinace vitamínu E a testosteronu.

Tyto výsledky ukazují, že přídavek vitamínu E má signifikantně snižující účinek na testosteronem indukovanou aktivitu arginázy v ledvinách a působí tak na ní pozitivně.

\section{References}

ERISIR M, BEYTUT E, OZAN S, AKSAKAL M 2003: Effects of dietary vitamin E and selenium on arginase activity in the liver, kidney and heart of rats treated with high doses of glucocorticoids. Cell Biochem Funct 21: 331-335

FRIEDEN EH, FISHEL SS 1968: Differential sensitivity of parameters of androgen action to metabolic inhibitors: Arginase and B-Glucuronidase. Biochem Biophys Res Commun 31: 515-521

GALLO-TORRES HE 1980: Absorption, blood transport and metabolism of vitamin E. In: MACHLIN, LJ (Ed.): Comprehensive Treatise, Marcel Decker, New York, pp. 170-267

GEYER JW, DABICH D 1971: Rapid method for determination of arginase activity in tissue homogenates. Anal Biochem 39: 412-417

GROFTE T, JENSEN DS, GRONBAEK H, WOLTHERS T, JENSEN SA, TYGSTRUP N, VILSTRUP H 1998: Effects of growth hormone on steroid-induced increase in ability of urea synthesis and urea enzyme mRNA levels. Am J Physiol 275: E79-E86

HAGGERTY DF, SPECTOR EB, LYNCH M, KERN R, FRANK LB, CEDERBAUM SD 1983: Regulation expression of genes for enzymes of the mammalian urea cycle in permanent cell-culture lines of hepatic and nonhepatic origin. Mol Cell Biochem: 53/54: 57-76

HERZFELD A, RAPER SM 1976: The heterogeneity of arginases in rat tissues. Biochem J 153: 469-78

KAYSEN GA, STRECKER HJ 1973: Purification and properties of arginase of rat kidney. Biochem J 133: 779-788

KUMAR AN, KALYANKAR GD 1984: Effect of steroid hormones on age dependent changes in rat arginase isoenzymes. Exp Geront 19: 191-198

LOWRY OH, ROSENBROUGH NJ, FARR AL, RANDALL RJ 1951: Protein measurements with the folin phenol reagent. J Biol Chem 193: 265-275 
MANTEUFFEL-CYMBOROWSKA M 1993: Differential role of polyamines in hyperplasia and hypertrophy. Acta Biochim Polon 40: 383-388

MANTEUFFEL-CYMBOROWSKA M, CHMURZYNSKA W, GRZELAKOWSKA-SZTABERT B 1993: Polyamines in testosterone-induced hypertrophic and antifolate-induced hyperplastic mouse kidney. Differential effect of alpha-difluoromethylornithine. Biochim Biophys Acta 1182: 3-41

MANTEUFFEL-CYMBOROWSKA M, CHMURZYNSKA W, PESKA M, GRZELAKOWSKA-SZTABERT B 1995: Arginine and ornithine metabolizing enzymes in testosterone-induced hypertrophic mouse kidney. Int J Biochem Cell Biol 27: 287-95

MANTEUFFEL-CYMBOROWSKA M, PESKA M, CHMURZYNSKA W, GRZELAKOWSKA-SZTABERT B 1997: Catecholamines are required for androgen-induced ODC expression but not for hypertrophy of mouse kidney. Biochim Biophys Acta 1356: 292-298

MIMIC-OKA J, CUPIC Z, JAPUNDZIC I 1971: Effect of adrenal function on level of hepatic and extrahepatic arginase. Experientia 27: 1477-1478

PARK JR, TAPPEL AL 1991: Protein damage and lipid peroxidation: effects of diethyl maleate, bromotrichloromethane and vitamin $\mathrm{E}$ on ammonia, urea and enzymes involved in ammonia metabolism. Toxicol Letters 58: 29-36

PATNAIK SK, PATNAIK R 1989: Tissue-specific differential modulation of arginase and ornithine aminotransferase by hydrocortisone during various developmental stages of the rat. Biochem Intl 18: 709-719

POREMBSKA Z, GRABON W, ZELAZOWSKA E, CZECZOT H, ZAMECKA E 1993: Nonidentity of subunits of human kidney arginase A1 and human liver arginase A5. Acta Biochim Pol 40: 465-70

POREMBSKA Z, ZAMECKA E 1984: Immunological properties of rat arginases. Acta Biochim Pol 31:223-7

RATNER S, PETRACK B 1953: The mechanism of arginine synthesis from citrulline in kidney. J Biol Chem 200: 175-185

SKRYZPEK-OSIECKA I, POREMBSKA Z 1983: Hybridization of subunits of rat liver arginase A1 and rat kidney arginase A4. Acta Biochim Pol 30: 93-7

SPECTOR EB, RICE SCH, CEDERBAUM SD 1983: Immunologic studies of arginase in tissues of normal human adult and arginase-deficient patients. Pediatr Res 17: 941-4

SWANK RT, DAVEY R, JOYCE L, REID P, MACEY M 1977: Differential effect of hypophysectomy on the synthesis of beta-glucuronidase and other androgen-inducible enzymes in mouse kidney. Endocrinology 100: 473-80

YAMANAKA H, MAYUZUMI T, SHIMAZAKI J, SHIDA K. 1971: Properties and androgen-induced changes of arginase in kidney and ventral prostate of rats. Endocrinol Japon 18: 487-94 
